\title{
Sætningskløvninger koder fokus og non-fokus i dansk
}

\section{Marie Herget Christensen}

\begin{abstract}
It is a central claim in most Danish grammars that the Danish cleft construction encodes the clefted constituent with the function focus and that other sentence types do not have any grammatical focus encoding. This article will argue that not only does clefts encode focus, the construction also encodes the other part of the cleft - the cleft clause - with the anti-function of focus, non-focus. Further it will argue that while non-clefted sentence do not encode focus, they do encode both potential focus in one part and anti-focus in another part of the sentence. Thus, the article will show that focus structure in Danish consists of four different encodings making focus structure coding relevant for all sentence types in Danish.
\end{abstract}

\section{Nøgleord}

sætningskløvning, fokus, topologi, informationsstruktur, subjekter

\section{Indledning}

En af de mest omdiskuterede sætningskonstruktioner i dansk er den såkaldte sætningskløvning. Den tiltrækker sig opmærksomhed blandt grammatikforskere på grund af dens markerede topologi, dens alsidige brug, og dens iboende grammatiske kodninger der koder forskellige dele af sætningsindholdet med ganske forskelligartede funktioner. Denne artikel vil argumentere for at en af disse kodninger er nonfokus, det vil sige det 
modsatte af fokus. Sætningskløvninger er komplekse sætninger hvor én proposition kløves i to sætninger som i eksempel $(1)^{1}$.

$$
\text { Det var Ole der knaldede ruden (Hansen \& Heltoft 2011:1790) }
$$

I (1) bliver én proposition (Ole knaldede ruden) altså udtrykt med en oversætning med det led der udkløves (Ole) (herefter kaldt det udkløvede led), og en ledsætning med resten af propositionens indhold (der knaldede ruden) (herefter kaldt klovningsledsatning) (jf. fx Herget Christensen (2019) eller Hansen (1995) for udførlige beskrivelser af sætningskløvningens struktur). I en dansk grammatisk tradition er der bred enighed om at formålet med, og effekten af, denne udkløvning er at det udkløvede led fokuseres (Boye \& Harder, 2012; Diderichsen, 1946; Hansen, 1995; Hansen \& Heltoft, 2011 ; Nølke, 1984; Togeby, 2009 m.fl.) Men i modsætning til andre fokusatorer i dansk (fx emfatisk tryk eller fokuspartikler) sker der for kløvningers vedkommende ikke bare en markering af et enkelt led i en proposition. Tværtimod bliver propositionen delt i to og udtrykt med en kompleks sætning med en oversætning der indeholder det udkløvede led $(O l e)$, og en undersætning - kløvningsledsætningen - der indeholder resten af propositionen (der knaldede ruden). Hvorfor nu denne tilsyneladende meget omstændelige og komplekse topologi blot for en fokustilskrivning der kan opnås med væsentligt mindre radikale grammatiske virkemidler? Det spørgsmål bliver ikke besvaret alene ved at betragte kløvninger som fokustilskrivninger, og er emnet for denne artikel.

Sætningskløvning afviger fra den øvrige sætningsstruktur i dansk ved netop topologisk at specificere fokus. Hansen \& Heltoft (201 1: 78ff) fastslår således at fokus er underspecificeret $i$ alle andre typer sætninger $i$ dansk end kløvninger (fremover ukløvede sætninger). Men også ukløvede sætninger har en topologisk kodning der har at gøre med fokus. Her drejer det sig blot ikke om specificeret fokus, men om leddets fokuspotentiale (Hansen \& Heltoft 2011: 78ff). Led i indholdsfeltet er potentielt nemlig fokus i ukløvede sætninger, ifølge forfatterne. I denne artikel vil jeg opstille en firdelt fokusstruktur for både ukløvede og kløvede sætningers fokuskodninger.

1 I dansk er vi ikke færdige med diskussionen af hvilke sætningstyper vi skal kalde (ægte) kløvninger (jf. fx (Nølke, 1984) (Hansen, 1995) for diskussioner af såkaldte pseudokløvninger). Den diskussion kan jeg ikke gå ind i her, og jeg begrænser mig derfor til at forholde mig til den konstruktionstype der både konsekvent bliver betragtet som en kløvning og en fokusator i dansk, nemlig det-kløvningen eller sætningskløvningen, eksemplificeret i (1). 
De fire kodninger er non-fokus, potentielt fokus, fokus og anti-fokus. Alle fire begreber bruges af Hansen \& Heltoft (2011:78ff), men jeg sætter dem ind i en ramme af topologiske fokuskodninger specielt med henblik på at forklare kløvningers komplekse topologi.

Artiklen har følgende struktur: Først vil jeg redegøre for sætningskløvnings funktioner, og definere hvad vi forstår ved fokus. Derefter vil jeg argumentere for hvorfor sætningskløvning også koder non-fokus på trods af denne funktion ikke nævnes af de mange beskrivelser af sætningskløvning (med Lambrecht (2001) som en nævneværdig undtagelse). Derefter vil jeg forklare den firdelte fokusstruktur. Til sidst vil jeg diskutere nogle eksempler på kløvningsbrug hvor fokuskodningen er blevet betvivlet.

\section{Funktioner for satningskløvninger}

Inden jeg dykker ned i fokus i kløvninger, vil jeg ridse de øvrige funktioner for kløvninger op. Sætningskløvning er en konstruktion der er blevet forsket meget i, og der er derfor en omfattende international litteratur om konstruktionerne. Der er bred enighed om at presupposition er en grundlæggende funktion (jf. fx Lambrecht 2001), det vil sige at indholdet i den ene del af tvedelingen, nemlig kløvningsledsætningen, er kodet som præsupponeret. En måde at vise dette på er ved at betragte ledsætningens sandhedsværdi når oversætningen negeres. Præsuppositionen for (1): nogen smadrede ruden forbliver således sand også i den negerede kløvning det var ikke Ole der smadrede ruden.

Når det kommer til kløvninger medfører, tvedelingen ifølge Weinert \& Miller (1996) at dens funktioner så at sige er to sider af samme mønt: en funktion i den del af kløvningen funktionen virker i, og så det vi kunne kalde anti-funktionen i den anden del. Weinert \& Miller (1996) beskriver det for præsupposition. Kløvninger koder således ikke bare kløvningsledsætningen som præsupponeret, den koder også det udkløvede led som det modsatte, nemlig asserteret. Dette funktionspar er altså kodet uafhængigt af - men dog i sammenspil med - kløvningers fokuskodning.

Også i den danske tradition (Hansen \& Heltoft 2011:1790ff; Togeby 2009; m.fl.) betragter man kløvningsledsætningen præsupponeret. Det er bare ikke noget der er særligt centralt for de danske beskrivelser. Hansen \& Heltoft (2011: 1794) nævner det således som en del af beskrivelsen af sætningskløvning, men nævner det ikke som en central grammatisk funktion ved konstruktionen. Snarere som et særtræk ved konstruktionen der tilfældigvis er sådan. For dem er den centrale grammatiske funktion nemlig at kode fokus på det udkløvede led. Det er bemærkelsesværdigt for der ligger 
mig bekendt ikke noget iboende i en grammatisk fokuskodning der koder det ikke-fokuserede som præsupponeret. Det er altså noget ganske særligt ved kløvningskonstruktionen at den ud over at kode et led som fokus grammatisk, samtidig koder leddet som asserteret og resten af propositionen som præsupponeret.

Det er i litteraturen ganske ukontroversielt at fastslå at kløvninger præsupponerer. Men ved at navngive konstruktionen fokuskonstruktion (som fx Dik 1989 gør) og ved at beskrive kløvninger som den vigtigste grammatikaliserede måde at tilskrive fokus i dansk på (som Hansen \& Heltoft 2011:1790ff gør), er der ingen tvivl om at præsuppositionsfunktionen er blevet lidt stedmoderligt behandlet i litteraturen. Det er derfor godt at få slået fast at præsupposition også er en grundlæggende funktion ved kløvning. Rykker det ved om kløvninger også er fokusatorer? Jeg vil argumentere for at der ud over præsupposition/assertions-funktionsparret også er en iboende fokuskodning i kløvninger. Først må jeg imidlertid ridse baggrunden op for hvorfor det overhovedet er blevet betvivlet at kløvninger koder fokus.

\section{Fokus}

Som jeg vil vende tilbage til nedenfor, har de seneste årtiers korpusundersøgelser af kløvningers brug afsløret vældig alsidig brug af sætningskløvninger. Det har fået flere forfattere til at betvivle fokustilskrivning som den grundlæggende funktion ved kløvning. (jf. fx Collins (2006)). Delin (1989) tegner sig for en af de mest radikale udgaver af synspunktet. I konklusionen på sin afhandling om engelske kløvninger skriver hun:

"No definition of Focus so far suggested in relation to clefts can reliably be associated with clefts of all kinds, which casts considerable doubt on the popular assumption that clefts are 'focusing' constructions" (Delin 1989: 231)

Hun konkluderer at man i stedet bør tale om præpositionskonstruktioner fordi alle kløvninger har en præsuppositionsfunktion, og den altså er mere grundlæggende ifølge hende. Hun gennemgår en række forfatteres fokusdefinitioner, og finder dels stor variation i definitioner dels manglende udsigelseskraft i forhold til kløvningers faktiske brug og en stor grad af sammenblanding af forskellige niveauer i beskrivelsen. Således viser hun 
at fokus ofte forveksles eller blandes sammen med intonationsmønstre ${ }^{2}$ og med andre informationsstrukturelle forhold. Hvis vi skal kunne afgøre om fokus er en iboende kodning i kløvning, må vi altså entydigt kunne definere hvad fokus er. Det vil jeg gøre i næste afsnit.

\subsection{Fokusdefinitioner}

Først må vi adskille fokus fra andre informationsstrukturelle systemer. Når vi som lingvister prøver at beskrive informationsstruktur, kan vi hurtigt miste pusten fordi der, som Kristensen (2013) påpeger, er så mange divergerende definitioner og terminologiske uklarheder. Det skyldes efter min mening kompleksiteten i sproglig og tekstlig sammenhæng. Der er så mange forankringstråde frem og tilbage og ud af og ind i diskursen. Tit beskriver vi hver vores del af dette trådnet når vi som lingvister beskriver informationsstrukturen. Der er nemlig forskellige systemer der fungerer samtidigt og parallelt men næppe uafhængigt af hinanden. Der er en række informationsstrukturelle systemer som fungerer tekstpragmatisk på tværs af sætningstyper, og som ikke må forveksles med grammatisk kodet fokus, men ofte bliver det fordi systemer spiller sammen i den komplekse sproglige virkelighed. Hertil hører både intonation, tema-rema og ny-given informationsstruktur. Ingen tvivl om at disse systemer også er tilstede i kløvninger, men når vi vil beskrive kløvninger, må vi skelne mellem hvad der er iboende grammatiske fokuskodninger i en kløvning, og hvad der er pragmatiske forhold der gør sig gældende for specifik brug.

Delin (1989) hævder at fokusdefinitioner er for diffuse og for forskellige $o g$ at ingen af dem indfanger præcis funktionen af de mange forskellige kløvningsbrug. En del af udfordringen ligger for kløvningers vedkommende $\mathrm{i}$ at der sker en række ting samtidig i det udkløvede led. Der sker en syntagmatisk fremhævning af det udkløvede led (Boye \& Harder, 2012; Diderichsen, 1946; Sturt, Sanford, Stewart, \& Dawydiak, 2004). Samtidig vækker udkløvningen forestillingen om et paradigme af mulige referenter (Hansen \& Heltoft 2011:1794f). I (1) vækkes således forestillingen om mulige rudeknusere. Endvidere udpeges netop én referent i paradigmet (Ole) mens resten fravelges. Det vil sige Ole står i paradigme med de andre

2 Sammenspillet mellem kløvninger og intonationsmønstre er blevet undersøgt i stor stil for engelske kløvninger (jf. fx Collins 2006). Jeg vil ikke gå ind i det i denne artikel dels fordi kløvninger ikke kun forekommer i talesprog og derfor nødvendigvis må have kodninger der er uafhængige af intonationsmønstre, dels fordi intonationsmønstre adskiller sig i dansk og engelsk og der mig bekendt ikke foreligger undersøgelser af danske kløvningers intonationsmønstre. 
potentielle rudeknusere, men ved valget af Ole frikendes resten af paradigmet. Denne listeopstilling og udpegning er det andre forfattere har kaldt specifikation (jf. fx Patten, 2013; Weinert \& Miller, 1996), og fravalget af resten er blevet kaldt konstruktionens exhaustiveness og tilsvarende den udpegede referents uniqueness (jf. fx (Delin, 1989; Korzen, 2014b). Hvor mange af disse karakteristika man kan fă til at høre under fokus, kommer an på ens fokusdefinition. Groft sagt kan man sige at fokusdefinitioner enten forholder sig til det paradigmatiske aspekt "listeopstillingen" eller det syntagmatiske aspekt fremhævningen i forhold til andre led i sætningen. For paradigmedefinitionen er især Krifka (2008) fremherskende med sin definition af fokus som en markering af et sæt af mulige alternativer. I dansk tradition finder vi især variationer over syntagmatiske definitioner hvor fokus betegner henholdsvis den vigtigste (Boye \& Harder 2012), den mest centrale (Hansen \& Heltoft 2011: 78ff), eller den relevante (Togeby 1993; Jensen 2011) del af meddelelsen eller ytringen. Opsummerende kan jeg altså sige at fokus har to dimensioner: en syntagmatisk og en paradigmatisk. Syntagmatisk markeres ét led i forhold til de andre med en særlig prominens som vigtig og/eller relevant. Paradigmatisk markeres én referent som udvalgt i forhold til et paradigme som markeres som fravalgt (uden at blive udtrykt). Som jeg vil vende tilbage nedenfor, kan den ene af dimensionerne træde i baggrunden i visse kløvningsbrug.

\section{Satningskløvning koder fokus og antifokus}

Således har jeg altså præsenteret en definition for fokus der ikke er filtret sammen med andre informationsstrukturelle forhold og forskellig brug. I tråd med den danske tradition og Hansen \& Heltoft (2011) er det min analyse at der er en fokuskodning iboende i kløvningskonstruktionen. Men hermed er alt ikke forklaret for det udestår stadig at forklare hvorfor der skal en så omstændelig sætningskonstruktion til fokustilskrivning når andre operatorer (fx fokuspartikler) ikke også kræver en sætningsunderordning for at kunne fokusere. Det er fastslået at der også er en anden funktion i kløvningsledsætningen, nemlig præsupposition, men det kan ikke være forklaring eftersom andre fokusatorer ikke kræver at information uden for fokusatorens skopus bliver topologisk kodet som præsupponeret (jf. Hansen \& Heltoft 2011:78ff). 


\subsection{Kløvningsledsatningen koder antifokus}

Lambrecht (2001) fastslår i sin analyse af kløvninger at det udkløvede led på den ene side er forbundet med fokus, og at kløvningsledsætningen omvendt er forbundet med nonfocal. Jeg vil nu argumentere for at kløvningskonstruktionen har et funktionsmodsætningspar for fokus på samme vis som for præsupposition. Vi så at tvedelingen medfører at funktionens antifunktion kodes i den anden del af kløvningen. Når det udkløvede led koder fokus, må det altså følge at kløvningsledsætningen koder non-fokus. Non-fokusfunktionen er også beskrevet hos Hansen \& Heltoft (2011: 78ff). Således forklarer forfatterne at når fokus i en ukløvet sætning er specificeret af en fokusator, fx en fokuspartikel, så bliver den del af sætningen fokusatoren har synsvidde over fokuseret, og samtidig bliver resten af sætningen markeret som non-fokus. Min analyse af non-fokus ligger helt tråd hermed. Det nye jeg tilføjer, er blot at konstatere at hvis fokusatorer også markerer non-fokus, må det nødvendigvis være en iboende del af en konstruktion der topologisk koder fokus at den også topologisk koder non-fokus. Derfor må kløvningsledsætninger i dansk kode non-fokus.

Min analyse er altså at kløvningskonstruktioner deler en proposition op i to med det formål (blandt andet) at kode fokus i den ene del ved at udkløve det og samtidig kode antifunktionen i den anden del, nemlig non-fokus, ved at underordne indholdet i en ledsætning. Dette funktionsmodsætningspar er en iboende grammatisk kodning i konstruktionen, og er tilstede uafhængigt af (men dog i samspil med) det andet grundlæggende funktionsmodsætningspar, nemlig præsupposition og assertion. Begge funktionspar forbliver kodet i konstruktionen uanset brug. At kløvningskonstruktionen koder ikke bare fokus, men også antifunktionen for fokus, forklarer den omstændelige sætningsstruktur.

At hævde at non-fokus er en kodning, medfører også at der ikke bare er tale om fravær af fokus. Non-fokus er derimod en kodning i sin egen ret med sit eget grammatiske indhold. Den koder således det modsatte af fokus: det mindst vigtige, mindst centrale, og det som på ingen måder har alternativer. Det ligger snublende nært at mene at det der er kodet som det mindst relevante, det som ikke tilføjer information (for at tage antifunktionen Togebys 1993 fokusdefinition), i virkeligheden er en præsuppositionskodning - i hvert fald hvis man har en definition af præsupposition som det vi går ud fra, det vi tager for givet (jf. Harder \& Poulsen 1980). Og det er rimeligvis sådan at de to funktioner er forbundne. Men præsupposition har et andet betydningsdomæne end relevans og vigtighed. Præsupposition koder nemlig for sandhedsværdi (Delin 1989). Sammenhængen er ifølge min analyse at 
information kan kodes som non-fokus, altså som mindst vigtigt, centralt, eller relevant i kraft af at det allerede er kodet som præsupponeret, altså som sandt. Bemærk at disse forhold er i et andet domæne end spørgsmålet om hvorvidt informationen er ny eller given/kendt. Præsupponeret information vil ofte være given, men som Prince (1978) har vist, er det ikke altid tilfældet. For mig at se er det altså et argument for non-fokuskodningen at der er en præsuppositionskodning af ledsætningen.

At der er tale om en ledsætning - altså om et underordningsforhold er et andet argument. Flere har påpeget (jf. fx Collins 2006; Hasselgård 2004; Weinert \& Miller 1996) at kløvningskonstruktionen deler indholdet i to forskellige informationsenheder (med vandtætte skotter imellem. Derfor har de to deles respektive funktioner ikke synsvidde over den anden del). Det er også korrekt, men det er ikke to sideordnede informationsenheder. Tværtimod er der i kløvningskonstruktioner et helt klart underordningsforhold idet den ene sætning har alle de karakteristika vi forbinder med underordnede sætninger. Ledsætningen har dog voldt besvær for mange teoretikeres analyse blandt andet fordi det ikke står klart hvad den lægger sig til eller hvorfor den tilsyneladende er relativformet (Hansen, 1995). Uden her at kunne give en fyldestgørende analyse af ledsætningen i kløvningskonstruktioner, mener jeg at man kan se underordningen som ikonisk topologisk afspejling af funktionsmodsætningsparret. Det prominente, vigtige, det der er kodet som fokus, er således topologisk placeret i oversætningen, mens det mindst vigtige det der er kodet som non-fokus, er placeret i underordningen der topologisk må siges at være en mindre prominent placering end i oversætningen.

Et tredje argument for non-fokus findes i processeringen. Ved et forsøg jeg gennemførte der testede netop fokuseffekt af det udkløvede led, fandt jeg en fokuseringseffekt der medførte dybere processering af udkløvede led end af led i kløvningsledsætningen. Men derudover fandt jeg også en hel klar modsat effekt, nemlig en mindre dyb processering af kløvningsledsætninger end af led i indholdsfeltet i ukløvede sætninger. (Christensen \& Stewart, kommende). Denne dobbelte effekt (både forgrundseffekt af det udkløvede led og baggrundseffekt af kløvningsledsætningen) tolker jeg som argument for funktionsparrets iboende kodning i kløvninger. Det udkløvede led fokuseres med en syntagmatisk fremhævning med konsekvenser for processeringen til følge; kløvningsledsætningen "non-fokuseres" med en syntagmatisk baggrunding med tilsvarende konsekvenser for processeringen til følge.

Opsummerende kan jeg altså sige at min analyse er at kløvningskon- 
struktionen er en måde topologisk at kode - det vil sige specificere - både fokus og non-fokus i dansk. Det er den iboende kodning af fokus der får Hansen \& Heltoft (2011:1793) til at karakterisere kløvningskonstruktionen som den grammatikaliserede måde at udtrykke fokus på i dansk. Men når fokus udtrykkes med en kløvning, kodes antifunktionen nonfokus samtidig i kløvningsledsætningen. Det er særegent for kløvninger fordi ukløvede ikke har en topologisk kodning der specificerer fokus. Alligevel har de dog en topologisk kodning for fokusstruktur. Den beskriver jeg nedenfor.

\section{Ukløvede konstruktioners fokuspotentiale}

I ukløvede sætninger er fokus grammatisk underspecificeret (Hansen \& Heltoft 2011:78ff). Det vil sige at der ikke topologisk eller på anden måde er kodet ét led der er tilskrevet fokus. Fokus bestemmes i ukløvede sætninger så enten pragmatisk i talesituationen eller ved at afsender anvender særlige sproglige fokusatorer (fokuspartikler, emfatisk tryk mm.) der specificerer fokus. Men selvom fokus er underspecificeret i ukløvede sætninger, så er der også for disse sætningstyper topologiske kodninger der har at gøre med fokus. Hansen \& Heltoft (2011:78ff) påpeger nemlig at hvis fokus ikke specificeres, vil et led i indholdsfeltet i talesituationen blive tolket som fokus. De beskriver indholdsfeltet som fokusdomænet, og led placeret $\mathrm{i}$ indholdsfeltet som potentielt fokus. Om end fokus er underspecificeret i ukløvede sætninger, medfører placering henholdsvis i og uden for indholdsfeltet altså at leddet enten uden videre kan tolkes pragmatisk som fokus eller kun kan tilskrives fokus ved hjælp af særlige fokusatorer. Denne placeringsforskel er altså også en topologisk kodning for fokusstruktur, men den har at gøre med potentialet for fokus og ikke tilskrivningen af fokus. Hvor udkløvede led i kløvninger har en topologisk fokuskodning som fokus, har led placeret i indholdsfeltet altså den topologiske fokuskodning potentielt fokus.

\subsection{Placering uden for indholdsfeltet: anti-fokus}

Led placeret uden for indholdsfeltet - i særdeleshed udtrykssubjekter placeret på subjektspladsen - kan derimod ikke uden videre være fokus i ukløvede sætninger, ifølge Hansen \& Heltoft (2011:1743). Faktisk beskriver de subjekter som antifokus. Jensen (2011) viser dog at udtrykssubjekter i dansk godt kan være fokus, men at det kræver særlige sproglige fokusatorer, fx emfatisk tryk, placering af udtrykssubjektet i pladsen for ikonisk fokus eller fokuspartikel som eksemplificeret i (6). 
(2) So'fie kunne få noget mælk senere (med emfatisk tryk på udtrykssubjektet) (Jensen:201 1:200)

I (2) viser Jensen (2011) at udtrykssubjekters utilbøjelighed til fokus kan overvindes med særlige sproglige fokusatorer. Der er altså tale om en utilbøjelighed og ikke en umulighed. Den kodning benævner Hansen \& Heltoft (2011:1778) altså antifokus.

\subsection{Indholdssubjekter}

Ifølge Hansen \& Heltoft (2011: 78ff) er det som nævnt indholdsfeltet der er fokusdomæne. Alle led udenfor kan følgelig ikke være topologisk kodet som potentielt fokus. Men især subjektet er sat i forbindelse med anti-fokus (jf. Jensen 2011). Den begrænsede plads jeg her har til rådighed afholder mig fra at forholde mig til andre led uden for indholdsfeltet i ukløvede sætninger og deres fokusstruktur, men især de frie adverbialers fokusstruktur vil være interessant at undersøge i fremtidig forskning. For nuværende vil jeg se nærmere på forholdet mellem subjekt og antifokus.

Først og fremmest må vi holde os for øje om vi taler om indholdssiden eller udtrykssiden. Topologi hører til på udtrykssiden, og derfor har propositionen ingen fokuskodninger, heller ikke indholdssubjektet. Men når et indholdssubjekt udtrykkes som udtrykssubjekt i en ukløvet sætning, udtrykkes det altså med en medfølgende topologisk kodning som antifokus, og skal derfor bruge en særlig subjektsfokusator for at kunne fokuseres. Når et indholdssubjekt derimod udtrykkes som det udkløvede led i en kløvningskonstruktion, udtrykkes det med en medfølgende topologisk kodning som fokus. Det kan være en motivator for at udkløve indholdssubjekter i dansk. Korzen (2014b) finder flere subjektskløvninger i dansk end i italiensk, og sætter det i forbindelse med dansks V2-struktur. Også Weinert \& Miller (1996) foreslår at motivationen for at kløve kan være forskellig alt efter hvilken syntaktisk funktion der udkløves. Korzen (2014b: 173) finder at 66 $\%$ af de danske kløvninger i hans data er subjektskløvninger. Hans korpus består af udskrevne taler fra Europa-Parlamentet, det såkaldte Europarlkorpus. Dyhr (1978: 166) finder at $57 \%$ af de danske kløvninger i hans korpus af avisartikler og skønlitterære tekster er subjektskløvninger. Det viser at udkløvning er en anvendt strategi til at fokusere indholdssubjekter i dansk. Men for at få et billede af hvor hyppig strategien er, ville det kræve en undersøgelse af hvor ofte fokuserede indholdssubjekter udtrykkes som udkløvede led sammenlignet med hvor ofte de udtrykkes som udtrykssubjekter i ukløvede sætninger med en subjektsfokusator, samt hvor ofte de 
udtrykkes på andre måder, fx i indholdsfeltet som udtryksobjekter. Sådan en undersøgelse findes mig bekendt endnu ikke. Som nævnt er det udtrykssubjekter i ukløvede sætninger der er kodet som antifokus, men Hansen \& Heltoft (2011:1728ff) fastslår at det er subjektsplacering der koder antifokus. Subjekter kan imidlertid også placeres et andet sted i ukløvede sætninger, til og med et sted som af nogle forfattere er blevet forbundet med netop fokus (jf. Hansen \& Heltoft (2011:1728ff) for en oversigt). Den placering er fundamentfeltsplacering.

\subsection{Fundamentfeltsplacering}

Hansen \& Heltoft (2011: 1728ff) skriver at led fra indholdsfeltet kan være fokusled når det placeres i fundamentfeltet (forfeltet), og fundamentfeltet kan indeholde et fokusled. Men de skriver også at fundamentfeltsplacering i sig selv ikke medfører fokusering. Som jeg læser dem, kan fundamentfeltet indeholde fokusled når det $i k k e$ indeholder tema. Derfor er fundamentfeltet ikke fokusled, men derimod emneled, når subjektet er placeret i fundamentfeltet (Hansen \& Heltoft 2011:1728ff) ${ }^{3}$. Eftersom udtrykssubjektet er et led uden for indholdsfeltet, tolker jeg dem sådan at heller ikke subjekter i fundamentfeltet er kodet som potentielt fokus. Men de fastslår at det er subjektspladsen der koder anti-fokus. Fundamentfeltets topologiske kodninger er komplekse og omdiskuterede, og den topologisk fokusstruktur for fundamentfeltsplacerede indholdssubjekter i ukløvede sætninger må undersøges nærmere i fremtidig forskning.

For at opsummere kan det altså fastslås at den topologiske fokuskodning der findes i ukløvede sætninger har at gøre med potentiale og ikke faktisk fokustilskrivning. Placering i indholdsfeltet koder potentielt fokus som medfører at et led med kodningen i de rette pragmatiske (eller lingvistisk specificerede) omstændigheder uden videre kan tolkes som fokus. Placering uden for indholdsfeltet koder antifokus som medfører at leddet ikke uden videre har potentiale til at være fokus, men at der skal specielle lingvistiske midler til.

3 For Hansen \& Heltoft (2011:1778ff) er der forskellige meddelelsesstrukturer i dansk. Enten emnekommentar hvor fokus er at finde i kommentaren eller fokus - bagrund. Men bemærk at andre forfattere (jf. Jensen 2011 ) påpeger at emnet i sætning godt samtidig kan være fokus. 


\begin{tabular}{|l|l|l|l|}
\hline \multicolumn{4}{|c|}{ Topologiske fokuskodninger i dansk } \\
\hline Udtryk & Eksempel & Indhold \\
\hline Ukløvede sætninger & Subjektsplads & $\begin{array}{l}\text { Senere kunne Sofie } \\
\text { få noget mælk }\end{array}$ & Anti-fokus \\
\cline { 2 - 4 } & Indholdsfelt & $\begin{array}{l}\text { Sofie kunne få noget } \\
\text { mælk senere }\end{array}$ & Potentielt fokus \\
\hline Kløvede sætninger & Udkløvet led & $\begin{array}{l}\text { Det var Sofie der } \\
\text { kunne få noget mælk } \\
\text { senere }\end{array}$ & Fokus \\
\cline { 2 - 4 } & Kløvningsledsætning & $\begin{array}{l}\text { Det var Sofie der } \\
\text { kunne få noget } \\
\text { mælk senere }\end{array}$ & Non-fokus \\
\hline
\end{tabular}

Tabel 1: skema over de topologiske kodninger vi har til rådighed i dansk angående fokus. Eksemplet bygger på Jensen (2011).

\section{Den firdelte fokusstruktur i dansk}

Jeg kan nu sammenfatte de fire topologiske kodninger for fokusstruktur vi har i dansk. De fremgår af Tabel 1. Kodningen for kløvningers vedkommende drejer sig om faktisk fokus, og for ukløvede sætninger drejer det sig om potentialet for fokus.

Topologisk kodet fokus er altså kun tilstede i udkløvede led i dansk. Denne kodning medfører slet og ret at leddet altid er fokuseret. Omvendt medfører topologisk kodet non-fokus, som i dansk er kløvningsledsætninger, at leddene er markeret som de mindst centrale for meddelelsen. Led der er kodet som nonfokus kan ikke fokuseres, ${ }^{4}$ men er tværtimod markeret som ikke-centrale.

Topologisk kodning som potentielt fokus findes $\mathrm{i}$ indholdsfeltet $\mathrm{i}$ ukløvede sætninger i dansk. Kodningen medfører at led med denne kodning kandiderer til at være sætningens fokus, og ikke behøver en lingvistisk markering. Hvilken kandidat der vinder, afgøres af tekstpragmatiske forhold hvis ikke sætningen indeholder en fokusator, $\mathrm{fx}$ en fokuspartikel. Omvendt medfører topologisk kodning som anti-fokus at leddet ikke umiddelbart kandiderer til at være fokus, men kun kan fungere som fokus ved hjælp af en fokusator. Denne kodning har leddene uden for indholdsfeltet i ukløvede sætninger i dansk. Jeg har her kun medtaget de topologiske kodninger. For ukløvede sætninger kan fokus som nævnt altid specificeres med sproglige fokusatorer.

4 Bemærk at led i kløvningsledsætninger kan have sekundært fokus i visse tilfælde som Hansen og Heltoft (2011:1790ff) kalder "dobbeltfokus" fx det var Ole der smadrede "ruden (Og Hanne der smadrede klaveret), men i de tilfælde er netop tale om sekundært fokus. Led i kløvningsledsætninger kan aldrig i sig selv være fokuserede, netop i kraft af at det udkløvede led er fokuseret. 
Men når det sker, vil der ifølge Hansen \& Heltoft (2011: 78ff) blive lagt et ekstra lag af betydning ned over sætningen - fokusspecificeringen er med andre ord ikke topologisk kodet. Nu hvor fokusstrukturen for kløvninger er beskrevet udførligt, kan jeg som det sidste diskutere nogle af de eksempler på kløvningsbrug der er blevet fremsat i litteraturen som modeksempler på at kløvninger er fokuskonstruktioner.

\section{Fokuserer denne kløvning?}

Siden Prince (1978) begyndte at undersøge faktisk forekommende kløvninger i korpora, har adskillige korpusundersøgelser slået fast at brugen af kløvninger er meget mere varieret, både stilmæssigt og funktionsmæssigt end skolebogsgrammatikeksempler som (1) giver anledning til at tro (Collins, 2006; De Cesare, Garassino, Marco, \& Baranzini, 2014; Delin, 1989; Hasselgård, 2004; Herget Christensen, 2019; Korzen, 2014a; Patten, 2013; Prince, 1978; Weinert \& Miller, 1996) mfl.).

Blandt eksemplerne er Princes (1978) såkaldte IP-kløvning (informative presupposition cleft). Desr er det-kløvninger som (3) hvor ny information bliver introduceret i den præsupponerede ledsætning:

(3) It was fifty years ago today that Henry Ford gave us the weekend (Prince 1978:898)

Derudover nævnes den såkaldt emotive kløvning (Korzen, 2014b). Den bliver af Hansen \& Heltoft (2011:1796) beskrevet som en særlig retorisk brug af sætningskløvningen. Det er eksempler som (4):

$$
\begin{aligned}
& \text { "Det er med stor sorg og vemod, jeg har modtaget meddelelsen om } \\
& \text { Nelson Mandelas død." (Helle Thorning-Schmidt 06.12.203 http:// } \\
& \text { www.stm.dk/_p_13952.html) }
\end{aligned}
$$

Fælles for (2) og (3) synes at være at det næppe kan være hovedmeddelelsen der findes i det udkløvede led hvilket altså har fået en række forfattere (jf. fx Korzen (2014b)) til at betvivle at disse led er fokuserede. Endvidere er der fundet brug hvor det lader til at det er andre aspekter ved udkløvningens funktion end fokus der er motivationen for at kløve. Den såkaldte nyhedskløvning (Herget Christensen, 2019) i (4) er eksempel på dette.

(5) Det var muligvis en røggaseksplosion, der natten til søndag jævnede en villa i Brøndby med jorden. (Herget Christensen 2019:21) 
I (5) rammer operatoren muligvis kun det udkløvede led, mens det i en ukløvet sætning ville have ramt hele propositionen. Hansen (1995) gør desuden opmærksom på et særligt tilfælde af kløvning hvor det er spørgsmål der kløves. (6) er et eksempel herpå.

(6) [Albin spørger] ska vi ikke ha en calvados? hun rødmer:

- Hvad er det nu det er? (Trier Mørch 1980:35)

Som Hansen \& Heltoft (2011:1790ff) påpeger er hv-ord i spørgsmål i sig selv fokusled, så det forekommer altså at være dobbeltkonfekt med udkløvningen af hoad $\mathrm{i}(6){ }^{5}$

(3)-(6) viser tilsyneladende variation i funktionen for det udkløvede led, og endda et misforhold mellem kodning og brug. Der findes en række analysebud der adresserer dette misforhold. De mest radikale er helt at afvise enten brugen eller kodningen. Således fraskriver Togeby (2009) eksempler som (4) at være kløvninger eftersom han betragter dem som misbrug og altså ikke som kompetent sprogbrug. Ligeledes så vi ovenfor at Delin (1989) fraskriver fokus som en grundlæggende funktion ved kløvninger. Hvis man ser bort fra disse vældig radikale analyser, findes der to plausible bud. Det første er at fokustilskrivningen kan gradueres. I en dansk sammenhæng analyserer Korzen (2014a, 2014b) fokustilskrivningen i kløvninger som et gradsspørgsmål sådan at "prototypiske" eksempler som (1) har en stærk fokus markering, mens (3) og (4) har en svag og meget svag fokusmarkering henholdsvis. I forhold til grammatisk kodning er denne analyse ikke attraktiv fordi grammatiske kodninger i udgangspunktet er binære. Den anden analyse står Hansen \& Heltoft (2011: 1790ff) for. De analyserer som sagt (3) som retorisk brug. Man kan sige at det at markere et led der ikke fungerer som fokus i sætningen, er en særlig stilistisk effekt. Men effekten opstår netop på grund af spændingen mellem brug og kodning - på samme måde som et retorisk spørgsmål er kodet som et spørgsmål uden at fungere som det i sætningen. Den retoriske effekt ville ikke opstå hvis den grammatiske form (kodningen) ikke stadig var tilstede. Endelig kan det tilføjes at de forskellige dimensioner af fokus højst sandsynligt spiller en forskellig rolle i forskellig brug.

5 Det fører for vidt med en analyse af kløvede spørgsmål i denne artikel, men det er et vigtigt område for den videre forskning. 


\section{Konklusion}

I denne artikel har jeg argumenteret for at kløvningskonstruktionen i dansk koder både fokus og non-fokus. Selvom brugen af kløvninger er meget alsidig og kan være motiveret af forskellige aspekter af kløvningskonstruktionens funktioner, ændrer det ikke på at konstruktionen alt andet lige har en iboende topologisk kodning for fokus og en for non-fokus. Kodningerne medfører en markering som henholdsvis det mest og mindst centrale, vigtige, og relevante i meddelelsen. Ukløvede sætninger derimod har ikke en topologisk kodning for fokus og non-fokus, men en for fokuspotentiale. Således koder placering i indholdsfeltet potentielt fokus, mens placering udenfor koder anti-fokus.

Denne artikel har kun beskæftiget sig med det-kløvninger, men der er en række andre konstruktioner der også antages at dele propositioner i to i dansk. Det drejer sig om der-kløvninger (der er en pige der kan få malk senere), og de såkaldte pseudokløvninger (Hvem der kan fä malk senere, er Sofie og Sofie er den der kan fä malk senere). De vil være interessante at undersøge i kommende forskning fordi de typisk ikke betegnes som fokuskonstruktioner i dansk tradition, mens de bliver det i en international (jf. fx (Lambrecht, 2001; Prince, 1978; Weinert \& Miller, 1996)). Derudover har jeg i særlig grad forholdt mig til indholdssubjekter fordi de i ukløvede sætninger placeres uden for indholdsfeltet (når de udtrykkes som udtrykssubjekter). Der er imidlertid også andre led der er uden for indholdsfeltet når de udtrykkes i ukløvede sætninger, og som derfor også er interessante at se på i forhold til deres topologiske kodning. Særligt er de frie adverbialer interessante i fremtidig forskning.

\section{Om forfatteren}

Marie Herget Christensen er ph.d.-stipendiat ved Institut for Nordiske Studier og Sprogvidenskab, NorS, Københavns Universitet.

\section{Litteratur}

Boye, K., \& Harder, P. (2012): A usage-based theory of grammatical status and grammaticalization. Language, 88(1), 1-44. doi:10.2307/41348882

Christensen, M. H., \& Stewart, A. (kommende). Change blindness effects of word position in clefts and non-clefts in Danish.

Collins, P. (2006): It-clefts and wh-clefts: Prosody and pragmatics. fournal of Pragmatics, 38(10), 1706-1720. 
De Gesare, A.-M., Garassino, D., Marco, R. A., \& Baranzini, L. (2014): Form and frequency of Italian Cleft constructions in a corpus of electronic news. Frequency, Forms and Functions of Cleft Constructions in Romance and Germanic: Contrastive, Corpus-Based Studies, 281, 49.

Delin, J. L. (1989): Cleft constructions in discourse. PhD afhandling. University of Edinburgh

Diderichsen, D. (1946): Elementer dansk grammatik. København: Gyldendalske boghandel - Nordisk forlag.

Dik, S. C. (1989): The Theory of Functional Grammar, Part 1: The Structure of the Clause.Mouton de Gruyter.

Hansen, E. (1995): Sætningskløvning i moderne dansk. Danske Studier (Årgang 1995), 126-146.

Hansen, E., \& Heltoft, L. (2011): Grammatik over det danske sprog. Bind 3 : Setningen og dens konstruktion. København: Det danske Sprog- og Litteraturselskab.

Harder, P., \& Poulsen, A. (1980): Hvad går vi ud fra?: Om forudsatninger i sprog og handling.København: Gyldendal.

Hasselgård, H. (2004): Adverbials in IT-cleft constructions. Language and Computers, 49(1), 195-211.

Herget Christensen, M. (2019): Nyhedskløvningen. NyS, Nydanske Sprogstudier.

Jensen, E. S. (201 1): Er subjekt virkelig antifokus? Paper presented at the Møde om Udforskningen af Dansk Sprog, Aarhus.

Korzen, I. (2014a): Cleft sentences. Italian-Danish in contrast. I: Frequency, Forms and Functions of Cleft Constructions in Romance and Germanic: Contrastive, Corpus-Based Studies, 281, 217.

Korzen, I. (2014b): Firkløvning: En typologisk-komparativ beskrivelse af sætningskløvninger med eksempler fra dansk og italiensk. Ny forskning $i$ grammatik, 21, 163-176.

Krifka, M. (2008): Basic notions of information structure. Acta Linguistica Hungarica, 55(3-4), 243-276.

Kristensen, L. B. (2013): Context, you need: experimental approaches to information structure processing. Københavns Universitet, Det Humanistiske Fakultet.

Lambrecht, K. (2001): A framework for the analysis of cleft constructions. Linguistics, 39 (3; ISSUE 373), 463-516.

Nølke, H. (1984): Clefting in Danish? NyS, Nydanske Sprogstudier, 14(14), 72-111.

Patten, A. (2013): The English IT-cleft: A constructional account and a diachronic investigation (Vol. 79): Walter de Gruyter. 
Prince, E. F. (1978): A comparison of wh-clefts and it-clefts in discourse. Language, 883-906.

Sturt, P., Sanford, A. J., Stewart, A., \& Dawydiak, E. (2004): Linguistic focus and good-enough representations: An application of the changedetection paradigm. Psychonomic Bulletin \& Review, 11(5), 882-888.

Togeby, O. (1993): Praxt,Pragmatisk Tekstteori. Aarhus: Aarhus Universitetsforlag.

Togeby, O. (2009): Ordkløveri? Om sætningskløvning på dansk. I: Therkelsen, R. \& Jensen, E.S. (red.), Dramatikken i grammatikken (pp. 439-455). Roskilde: Institut for Kultur og Identitet, Roskilde Universitet.

Weinert, R., \& Miller, J. (1996): Cleft constructions in spoken language. fournal of Pragmatics, 25(2), 173-206. 